\title{
RÓWNOWAGA FINANSÓW PUBLICZNYCH A PROCES EUROPEJSKIEJ INTEGRACJ WALUTOWEJ W DOBIE GLOBALNEGO KRYZYSU
}

\begin{abstract}
WSTĘP
Globalny kryzys ekonomiczny wywarł istotny wpływ na wiele dziedzin gospodarki światowej. Poza - można rzec, typowym - oddziaływaniem na tempo wzrostu produkcji i dochodu przyczynił się do przemian również na innych płaszczyznach. Jedną z nich stanowią finanse publiczne, a w szczególności ich równowaga, której utrzymanie czy osiągnięcie sprawia władzom wielu krajów nawet w czasach rozkwitu gospodarczego dużo problemów. Równowaga budżetowa jest dodatkowo jednym $\mathrm{z}$ ważniejszych wyznaczników procesu integracji walutowej w Europie, odpowiedni poziom wskaźników jej dotyczących stanowi bowiem warunek konieczny przystąpienia do strefy wspólnego pieniądza.

Przedmiotem niniejszego opracowania jest przedstawienie wyników analizy wpływu największego kryzysu ostatnich lat na stopień zrównoważenia finansów publicznych w krajach Unii Europejskiej i, co z tym się wiąże, na proces dalszego rozszerzania strefy euro. W pierwszej części artykułu przypomniano istotę $\mathrm{i}$ interpretację fiskalnych kryteriów konwergencji, a także prezentowany w dostępnej literaturze teoretyczny wpływ depresji na wskaźniki budżetu państwowego. $\mathrm{Na}$ stępnie skupiono się na przebiegu zjawisk kryzysowych w gospodarkach krajów, które posługują się wspólnym pieniądzem, i wreszcie zasygnalizowano ich znaczenie dla państw, które jeszcze nie są pełnoprawnymi członkami Unii Gospodarczej i Walutowej. Jako metody badawcze wykorzystano te najbardziej typowe dla nauk ekonomicznych, czyli analizę literatury i analizę statystyczną. Okres badawczy to lata 2008-2010, przedstawiono także prognozy na rok 2011 i 2012.
\end{abstract}




\section{FISKALNE KRYTERIA KONWERGENCJ}

Kryteria konwergencji, określone w Traktacie z Maastricht i decydujące o dopuszczeniu krajów Unii Europejskiej do strefy wspólnego pieniądza, dotyczą pięciu podstawowych wskaźników makroekonomicznych - tempa wzrostu cen, długoterminowej stopy procentowej, kursu walutowego oraz salda i zadłużenia finansów publicznych. Dodatkowo ważna jest również zgodność przepisów krajowych $\mathrm{z}$ ustawodawstwem wspólnotowym (w tym ze statutem Europejskiego Banku Centralnego) w zakresie zasad funkcjonowania banku centralnego, emisji pieniądza, sposobu organizacji i prowadzenia polityki monetarnej itp. ${ }^{1}$

O ile kryteria zbieżności (konwergencji) dotyczące mierników monetarnych są skonstruowane zasadniczo w sposób dość kategoryczny, tzn. przekroczenie dopuszczalnych limitów ${ }^{2}$ automatycznie dyskwalifikuje dany kraj, jeśli chodzi o akcesję do strefy euro (o czym parę lat temu boleśnie przekonała się Litwa), o tyle warunki dotyczące sfery finansów publicznych są już znacznie bardziej łagodne w swoim wydźwięku. Zgodnie bowiem z postanowieniami traktatowymi państwo aspirujące do strefy wspólnej waluty nie może być objęte tzw. procedurą nadmiernego deficytu. Stwierdzenia nadmiernego deficytu dokonuje Rada Unii Europejskiej na zalecenie Komisji, kierując się dwoma wskaźnikami: relacją salda sektora oraz długu publicznego do $\mathrm{PKB}^{3}$. Istnienie „nadmiernego” deficytu nie wynika zatem automatycznie $\mathrm{z}$ przekroczenia dozwolonych pułapów mierników, ale $\mathrm{z}$ decyzji organów wspólnotowych. Dodatkowo Traktat stwierdza, że zbyt wysokie ujemne saldo budżetowe jest dopuszczalne, jeśli deficyt „zmniejszył się znacznie oraz w sposób stały i osiągnął poziom bliski wartości odniesienia lub przekroczenie wartości odniesienia ma charakter wyjątkowy oraz tymczasowy i stosunek ten pozostaje bliski wartości odniesienia" ${ }^{4}$. Podobnie względem zadłużenia publicznego stwierdza się, że jego dowolny pułap jest akceptowalny, jeśli „zmniejsza się dostatecznie i zbliża się do wartości odniesienia w zadowalającym tempie”.

\footnotetext{
1 Art. 104, 108 i 121 Traktatu ustanawiającego Wspólnotę Europejską (OJ C 321, 29.12.2006, s. 37).

2 Warto przypomnieć, że limity te są określone w sposób następujący: inflacja nie może być większa o więcej niż 1,5 punktu procentowego od średniej arytmetycznej z trzech krajów Unii Europejskiej o najbardziej stabilnych cenach, długoterminowa stopa procentowa nie może przekraczać o więcej niż 2 punkty procentowe średniej z tych samych trzech państw, a kurs rynkowy danej waluty powinien przez co najmniej dwa lata mieścić się w przedziale - zasadniczo - $\pm 15 \%$ względem kursu centralnego bez przeprowadzania dewaluacji (art. 1, 3 i 4 Protokołu w sprawie kryteriów określonych w artykule 121 Traktatu ustanawiającego Wspólnotę Europejską dołączonego do Traktatu).

Art. 104 i 121 ust. 1 Traktatu.

Art. 104 ust. 2 pkt a Traktatu.

Art. 104 ust. 2 pkt b Traktatu.
} 
Wspomniane wartości odniesienia mierników - tj. odpowiednio 3 i 60\% PKB danego państwa - określone zostały w protokole załączonym do Traktatu z Maastricht ${ }^{6}$, co może wskazywać na fakt, że intencją krajów członkowskich UE było zachowanie pewnej elastyczności, jeśli chodzi o ich wysokość; ewentualna zmiana treści protokołu jest bowiem z politycznego i proceduralnego punktu widzenia łatwiejsza niż zmiana traktatu${ }^{7}$. Na marginesie należy zaznaczyć, że w protokole tym można także odnaleźć definicję pojęcia sektora finansów publicznych. I tak, w świetle norm w nim zawartych, a także zgodnie z późniejszymi rozporządzeniami Rady UE, oznacza ono tzw. sektor general government, tj. domenę „całej władzy publicznej, czyli rządu centralnego, władz regionalnych lub lokalnych i funduszy ubezpieczeń społecznych".

Warto podkreślić, że omawiane złagodzenie podejścia do wypełniania kryteriów fiskalnych wykorzystywane było dotychczas szczególnie często przy ocenie poziomu długu publicznego. W okresie tworzenia strefy wspólnego pieniądza jedynie w przypadku trzech przystępujących do niej krajów (Finlandii, Francji i Luksemburga) w roku referencyjnym (tj. 1997) wartość zadłużenia była niższa niż 60\% PKB, a trzy z nich (Belgię, Grecję i Włochy) charakteryzował dług nawet wyższy niż $100 \%$ rocznego $\mathrm{PKB}^{9}$. Podobna sytuacja istniała w przypadku Malty i Cypru, gdzie w roku odniesienia (tj. 2006) dług w stosunku do PKB wyniósł odpowiednio 66,5 i $65,3 \%{ }^{10}$.

Co istotne, wszczęcie względem danego kraju procedury nadmiernego deficytu nie tylko zamyka mu drogę do strefy euro, ale także (przynajmniej teoretycznie) może wiązać się z różnego rodzaju sankcjami, co jest szczególnie istotne dla państw, które już posługują się wspólną walutą i których nie motywuje do utrzymywania odpowiedniego salda i zadłużenia finansów publicznych konieczność wypełnienia kryteriów konwergencji. Traktat z Maastricht wśród tego rodzaju sankcji, stosowanych zwłaszcza przy uporczywym uchylaniu się przez władze danego państwa od obowiązku zrównoważenia budżetu, wymienia: obwieszczenie zaleceń Rady względem sytuacji fiskalnej kraju, konieczność publikowania dodatkowych informacji przy emisjach papierów wartościowych, rewizję polityki kredytowej Europejskiego Banku Inwestycyjnego względem danego państwa, Traktatu.

Art. 1 Protokołu w sprawie procedury dotyczącej nadmiernego deficytu dołączonego do

7 Por. D. Sobczyński, Euro. Historia, praktyka, instytucje, KiK, Warszawa 2002, s. 36; L. Oręziak, Euro. Nowy pieniadz, Wyd. Nauk. PWN, Warszawa 2003, s. 34-35.

8 Art. 2 Protokołu w sprawie procedury, por. także art. 1 ust. 2 Rozporzqdzenia Rady (WE) nr 479/2009 z dnia 25 maja 2009 r. o stosowaniu Protokotu w sprawie procedury dotyczacej nadmiernego deficytu zatączonego do Traktatu ustanawiajacego Wspólnotę Europejska (OJ L 145, 10.06.2009, s. 1, z późn. zm.).

9 Convergence Report, European Monetary Institute, Frankfurt 1998, s. 25.

10 Convergence Report May 2007, Frankfurt: Europejski Bank Centralny 2007, s. 34 i 50. 
konieczność złożenia nieoprocentowanego depozytu i wreszcie możliwość nałożenia kary finansowej (grzywny) ${ }^{11}$.

Jak jednak podpowiada teoria makroekonomii, w warunkach kryzysu (czy recesji) w sferze finansów publicznych zachodzić mogą na tyle niekorzystne zjawiska, że nawet pomimo „dobrej woli” władz, które nie zamierzają istotnie pogłębiać nierównowagi fiskalnej czy nawet dążą do ustabilizowania sytuacji, relacja deficytu budżetowego i długu publicznego do PKB będzie się istotnie zwiększać. Finanse publiczne w okresie recesji spełniają bowiem również funkcję stabilizacyjną - pobudzają malejący popyt, czy to w sposób automatyczny, czy dyskrecjonalny. Zmniejszanie się salda budżetu wynika $z$ jednej strony z niższych wpływów podatkowych, na skutek spadku produkcji i dochodów lub celowego działania organów państwowych, a z drugiej - z rosnącej skali wydatków publicznych (chociażby na zasiłki dla bezrobotnych). Dlatego też zazwyczaj skutkiem recesji jest pogłębienie deficytu sektora, a w konsekwencji także zadłużenia publicznego ${ }^{12}$.

\section{KRYZYS A RÓWNOWAGA FINANSÓW PUBLICZNYCH W KRAJACH STREFY EURO}

$\mathrm{Za}$ początek globalnego kryzysu finansowo-gospodarczego, największego w ostatnich kilkudziesięciu latach, uznaje się moment pęknięcia „bańki” spekulacyjnej na rynku nieruchomości w USA w roku 2007. Zjawisko to miało swoją genezę w tzw. sektorze subprime, tj. kredytów hipotecznych skierowanych do osób o niewielkich dochodach. Jednak zasadnicze przyczyny kryzysu tkwiły dużo głębiej w gospodarce ogólnoświatowej i zgodnie z prezentowanymi w dostępnej literaturze ekonomicznej poglądami dotyczyły głównie różnego rodzaju i wagi nierównowag makroekonomicznych w skali globalnej, w takich sferach, jak rynek finansowy, wymiana międzynarodowa czy transgraniczne przepływy kapitału. $\mathrm{Na}$

\footnotetext{
11 Art. 104 ust. 8 i 11 Traktatu.

12 Wpływ cyklu koniunkturalnego na finanse publiczne i - vice versa - polityki fiskalnej na tempo wzrostu gospodarczego jest jednym z podstawowych problemów analizowanych w literaturze makroekonomicznej. Por. np. P.A. Samuelson, W.D. Nordhaus, Ekonomia, t. 1, PWN, Warszawa 1995, s. 280-281, 307-309; D. Begg, S. Fischer, R. Dornbusch, Ekonomia, t. 2, PWE, Warszawa 1998, s. 347-356; R.E. Hall, J.B. Taylor, Makroekonomia. Teoria, funkcjonowanie i polityka, Wyd. Nauk. PWN, Warszawa 1997, s. 136-137; R.J. Barro, Makroekonomia, PWE, Warszawa 1997, s. 264-272; M. Burda, Ch. Wyplosz, Makroekonomia. Podręcznik europejski, PWE, Warszawa 1995, s. 344-345; Makroekonomia, red. M. Noga, Wyd. AE, Wrocław 1995, s. 60-61; Polityka gospodarcza, red. B. Winiarski, PWN, Warszawa 2006, s. 388-389; D.R. Kamerschen, R.B. McKenzie, C. Nardinelli, Ekonomia, Fundacja Gospodarcza NSZZ „Solidarnośc”, Gdańsk 1992, s. 151-155; A. Müller, Makroekonomia, PWSH, Warszawa 1996, s. 199-203.
} 
wystąpienie zjawisk kryzysowych wpływ miały z pewnością również zasadniczo niskie realne stopy procentowe, a także determinanty mikroekonomiczne: niedoskonałe czy wręcz wadliwe systemy kontroli instytucji finansowych, nieefektywne sposoby szacowania przez nie ryzyka czy wreszcie błędne procedury motywacyjne stosowane wobec konsumentów i pracowników banków ${ }^{13}$.

Tabela 1. Kwartalny przyrost realnego PKB w krajach UE (w \%) w latach 2008-2010

\begin{tabular}{|l|c|c|c|c|c|c|c|c|c|c|c|c|c|}
\hline \multicolumn{1}{|c|}{ Rok } & \multicolumn{7}{|c|}{2008} & \multicolumn{7}{c|}{2009} & \multicolumn{3}{c|}{2010} & \multirow{2}{*}{$2008-2010^{*}$} \\
\hline \multicolumn{1}{|c}{ KrAJ } & I & II & III & IV & I & II & III & IV & I & II & III & IV & \\
\hline Łotwa & $-3,0$ & $-1,8$ & $-1,8$ & $-4,0$ & $-11,3$ & $-1,3$ & $-4,2$ & $-0,6$ & 1,0 & 1,2 & 0,9 & b.d. & $-21,8$ \\
\hline Estonia & $-2,2$ & $-1,0$ & $-2,6$ & $-5,7$ & $-5,6$ & $-3,7$ & $-1,3$ & 1,4 & 1,0 & 1,9 & 0,7 & b.d. & $-16,3$ \\
\hline Litwa & 1,0 & 0,4 & $-1,8$ & $-1,2$ & $-11,5$ & $-2,1$ & $-0,1$ & $-1,1$ & 1,4 & 1,0 & 0,3 & b.d. & $-11,9$ \\
\hline Irlandia & $-2,5$ & $-1,9$ & $-0,5$ & $-4,5$ & $-2,5$ & $-0,3$ & $-0,6$ & $-2,3$ & 2,1 & $-1,0$ & 0,5 & b.d. & $-11,0$ \\
\hline Grecja & 0,2 & 0,3 & $-0,2$ & $-0,4$ & $-1,1$ & $-0,4$ & $-0,7$ & $-1,1$ & $-0,6$ & $-1,7$ & $-1,3$ & b.d. & $-5,2$ \\
\hline Włochy & 0,4 & $-0,7$ & $-1,1$ & $-2,0$ & $-2,9$ & $-0,3$ & 0,4 & $-0,1$ & 0,4 & 0,5 & 0,3 & 0,1 & $-5,2$ \\
\hline Węgry & 1,2 & $-0,2$ & $-1,0$ & $-2,1$ & $-3,2$ & $-1,3$ & $-0,8$ & 0,1 & 1,4 & 0,2 & 0,6 & 0,2 & $-4,9$ \\
\hline Finlandia & 0,3 & 0,2 & $-0,4$ & $-3,1$ & $-5,6$ & $-1,1$ & 1,3 & 0,3 & 0,1 & 2,6 & 0,5 & 2,5 & $-4,7$ \\
\hline Dania & $-1,5$ & 0,7 & $-0,9$ & $-2,6$ & $-1,6$ & $-2,4$ & 0,4 & 0,5 & 0,7 & 1,3 & 1,0 & b.d. & $-4,1$ \\
\hline Słowenia & 1,7 & 0,7 & 0,2 & $-3,3$ & $-6,0$ & $-0,6$ & 0,4 & 0,1 & $-0,1$ & 1,0 & 0,3 & b.d. & $-3,7$ \\
\hline Wlk. Brytania & 0,5 & $-0,3$ & $-0,9$ & $-2,1$ & $-2,2$ & $-0,8$ & $-0,3$ & 0,5 & 0,3 & 1,1 & 0,7 & $-0,5$ & $-3,7$ \\
\hline Hiszpania & 0,5 & 0,0 & $-0,8$ & $-1,1$ & $-1,6$ & $-1,1$ & $-0,3$ & $-0,2$ & 0,1 & 0,3 & 0,0 & 0,2 & $-3,0$ \\
\hline Rumunia & 3,8 & 1,5 & $-0,4$ & $-2,2$ & $-4,1$ & $-1,5$ & 0,1 & $-1,5$ & $-0,3$ & 0,3 & $-0,7$ & b.d. & $-2,2$ \\
\hline Szwecja & $-1,1$ & 0,0 & 0,0 & $-4,1$ & $-2,6$ & 0,3 & $-0,1$ & 0,9 & 1,7 & 2,0 & 2,1 & b.d. & $-1,3$ \\
\hline Portugalia & 0,1 & $-0,1$ & $-0,6$ & $-1,4$ & $-1,6$ & 0,6 & 0,2 & $-0,2$ & 1,1 & 0,2 & 0,3 & b.d. & $-1,2$ \\
\hline Francja & 0,5 & $-0,6$ & $-0,3$ & $-1,6$ & $-1,4$ & 0,2 & 0,2 & 0,6 & 0,3 & 0,6 & 0,3 & 0,3 & $-0,8$ \\
\hline Holandia & 0,8 & $-0,2$ & $-0,2$ & $-1,3$ & $-2,3$ & $-1,3$ & 0,8 & 0,4 & 0,4 & 1,0 & 0,1 & 0,6 & $-0,4$ \\
\hline Niemcy & 1,4 & $-0,7$ & $-0,5$ & $-2,2$ & $-3,4$ & 0,5 & 0,7 & 0,3 & 0,6 & 2,2 & 0,7 & 0,4 & $-0,3$ \\
\hline Belgia & 0,8 & 0,5 & $-0,4$ & $-2,2$ & $-1,7$ & 0,1 & 1,0 & 0,4 & 0,1 & 1,1 & 0,4 & b.d. & 0,1 \\
\hline
\end{tabular}

13 Polska wobec światowego kryzysu gospodarczego, NBP, Warszawa 2009, www.nbp.pl (data dostępu: 04.01.2010 r.), s. 4-8; por. także np. A. Nosek, A. Pietrzak, Efekt domina czyli międzynarodowa transmisja kryzysów - na przyktadzie wspótczesnego kryzysu finansowego, [w:] Wybrane problemy gospodarki światowej pierwszej dekady nowego wieku, red. W. Michalczyk, Katedra MSG UE, Wrocław 2009, s. 85-90. 
cd. tab. 1

\begin{tabular}{|c|c|c|c|c|c|c|c|c|c|c|c|c|c|}
\hline \multirow{2}{*}{$\frac{\text { RoK }}{\text { KRAJ }}$} & \multicolumn{4}{|c|}{2008} & \multicolumn{4}{|c|}{2009} & \multicolumn{4}{|c|}{2010} & \multirow{2}{*}{$2008-2010^{*}$} \\
\hline & I & II & III & IV & I & II & III & IV & I & $\|$ & III & IV & \\
\hline Austria & 1,9 & 0,3 & $-1,0$ & $-1,6$ & $-2,1$ & $-0,8$ & 0,7 & 0,4 & 0,0 & 1,2 & 0,9 & 0,6 & 0,2 \\
\hline Czechy & 0,3 & 0,7 & 0,2 & $-0,9$ & $-3,6$ & $-0,5$ & 0,5 & 0,4 & 0,6 & 0,8 & 1,0 & b.d. & 0,7 \\
\hline Luksemburg & 1,8 & $-0,6$ & $-1,8$ & $-3,9$ & 0,6 & $-3,0$ & 3,3 & 1,3 & $-0,1$ & 0,9 & 1,5 & b.d. & 0,8 \\
\hline Bułgaria & 1,5 & 1,3 & 1,4 & 0,6 & $-6,3$ & 0,0 & $-0,1$ & $-0,2$ & $-0,5$ & 0,5 & 0,7 & b.d. & 0,9 \\
\hline Cypr & 0,9 & 1,2 & 0,3 & 0,0 & $-1,1$ & $-0,9$ & $-0,6$ & $-0,1$ & 0,6 & 0,6 & 0,8 & 0,3 & 2,3 \\
\hline Malta & 1,4 & 1,0 & $-0,1$ & $-1,5$ & $-1,7$ & $-0,1$ & 0,9 & 1,6 & 1,4 & 0,1 & 0,5 & b.d. & 3,9 \\
\hline Słowacja & $-1,4$ & 1,0 & 1,2 & 0,6 & $-7,6$ & 1,1 & 1,2 & 1,4 & 0,7 & 0,9 & 0,9 & 0,9 & 4,9 \\
\hline Polska & 1,4 & 0,7 & 0,8 & $-0,4$ & 0,4 & 0,6 & 0,4 & 1,4 & 0,7 & 1,2 & 1,3 & b.d. & 10,6 \\
\hline Unia Europejska & 0,6 & $-0,3$ & $-0,6$ & $-1,9$ & $-2,4$ & $-0,3$ & 0,2 & 0,3 & 0,4 & 1,0 & 0,5 & 0,2 & $-2,0$ \\
\hline Strefa euro & 0,7 & $-0,5$ & $-0,6$ & $-1,8$ & $-2,5$ & $-0,1$ & 0,4 & 0,2 & 0,4 & 1,0 & 0,3 & 0,3 & $-2,1$ \\
\hline
\end{tabular}

Źródło: opracowanie własne na podstawie danych Eurostatu, epp.eurostat.cec.eu.int (data dostępu: 21.02.2011 r.).

Szybkie rozprzestrzenienie się kryzysu we współczesnej gospodarce światowej - charakteryzującej się zjawiskami ogólnie określanymi mianem globalizacji ${ }^{14}$ - było właściwie nieuniknione. Negatywne zjawiska rychło przeniosły się z rynku nieruchomości USA na inne rynki, zarówno w układzie przedmiotowym (rynek papierów wartościowych, rynek instrumentów pochodnych, pozostałe rynki finansowe, wreszcie rynki towarów i usług), jak i geograficznym, do krajów o gospodarkach silnie związanych z amerykańską - państw rozwijających się, azjatyc-

14 Pojęcie globalizacji jest definiowane np. przez A. Zorską jako polegające na „długofalowym integrowaniu działalności na poziomie gospodarek, przemysłów/sektorów oraz przedsiębiorstw ponad granicami państw, dzięki rozszerzaniu, pogłębianiu oraz intensyfikowaniu różnego rodzaju powiązań [...], co prowadzi do tworzenia się współzależnego systemu ekonomicznego w skali światowej, czyli globalnej gospodarki” (A. Zorska, Korporacje transnarodowe. Przemiany, oddziatywania, wyzwania, PWE, Warszawa 2007, s. 17). Wobec postępującej integracji działalności i ścisłych powiązań pomiędzy krajami byłoby zatem wielce nieprawdopodobne, aby zjawiska kryzysowe, które miały swoją genezę w jednym $\mathrm{z}$ największych elementów składowych światowego systemu ekonomicznego - gospodarce Stanów Zjednoczonych, nie przeniosły się natychmiast do innych państw. 
kich czy amerykańskich, oraz krajów Unii Europejskiej. W tej ostatniej grupie gospodarek, do której kryzys dotarł - jak się uznaje - w II kwartale roku 2008 (wtedy odnotowano początek spadku realnego PKB) zarówno przyczyny „zarażenia” zjawiskami kryzysowymi, jak i głębokość ich skutków były zróżnicowane. Do niektórych krajów (np. Niemiec) kryzys dotarł przez kanał handlu zagranicznego, gdy załamał się eksport; w innych (Francja, Hiszpania, Irlandia) bezpośrednią przyczyną pojawienia się recesji był, podobnie jak w USA, kryzys na rynku nieruchomości ${ }^{15}$. Analiza kwartalnych zmian PKB wskazuje z kolei, że poszczególne państwa Unii Europejskiej także w różnym stopniu odczuły spowolnienie (tab. 1). Długość okresu recesji w takim ujęciu wahała się bowiem od jednego kwartału (Słowacja, Polska) do siedmiu-ośmiu (Estonia, Łotwa) czy nawet jeszcze więcej (Grecja, Irlandia). W trzyletnim okresie 2008-2010 również korekta realnego PKB była bardzo zróżnicowana - od wielkości sięgających minus 10-20\% (Łotwa, Estonia, Litwa, Irlandia) po wzrost na poziomie od 2\% do nawet 10\% (Cypr, Malta, Słowacja, Polska).

Globalny kryzys, poza bardzo zróżnicowaną skalą oddziaływania na tempo przyrostu PKB w poszczególnych krajach Wspólnoty, charakteryzował się także istotnie zdywersyfikowanym wpływem na równowagę finansów publicznych. Jeśli chodzi o kraje strefy euro (tab. 2), to najmniejszy negatywny wpływ na saldo sektora general government odnotowano w Estonii i na Malcie (tu saldo w relacji do PKB w okresie 2008-2010 nawet się poprawiło), a także, co warto podkreślić, w Grecji - po przejściowej zapaści w roku 2009 różnica w deficycie pomiędzy rokiem 2010 a 2008 wyniosła jedynie minus 0,2\% PKB (choć deficyt ten już w 2008 r. był bardzo wysoki - aż 9,4\% PKB). Największe załamanie salda wskazać należy w dwóch krajach o tradycyjnej, wieloletniej nadwyżce budżetowej - w Finlandii (spadek o 7,3\% PKB w okresie 2008-2010) oraz Irlandii - zmniejszenie aż o 25\% PKB (!). Obecnie (stan na rok 2010) kryterium konwergencji w zakresie salda finansów publicznych (deficyt nie większy niż 3\% PKB) spośród krajów strefy euro spełniają wyłącznie wspomniana Estonia i Luksemburg. Zgodnie z prognozami Komisji Europejskiej ${ }^{16} \mathrm{w}$ najbliższych latach utrzyma się występujące od roku 2009 zjawisko ujemnego salda sektora general government we wszystkich krajach posługujących się wspólnym pieniądzem europejskim, jednak jednocześnie w coraz większej liczbie państw deficyt powinien powracać do poziomu uznawanego za bezpieczny.

\footnotetext{
15 Polska wobec, s. 11.

16 General government data. Autumn 2010, Komisja Europejska 2010, ec.europa.eu (data dostępu: 21.01.2011 r.), s. 154 .
} 
Tabela 2. Wypełnianie fiskalnych kryteriów konwergencji przez kraje strefy euro w latach 2008$-2012$

\begin{tabular}{|c|c|c|c|c|c|c|c|c|c|c|c|c|}
\hline WSKaŹNIK & \multicolumn{6}{|c|}{ SALDO BUDŻETOWE W RELACII DO PKB (w \%) } & \multicolumn{6}{|c|}{ DŁug PUBLLCZNY w RELACI DO PKB (w \%) } \\
\hline Rok & 2008 & 2009 & $2010^{*}$ & $2011^{*}$ & $2012^{*}$ & $2008-2010 \wedge$ & 2008 & 2009 & $2010^{*}$ & $2011^{*}$ & $2012^{*}$ & 2008-2010^ \\
\hline Austria & $-0,5$ & $-3,5$ & $-4,3$ & $-3,6$ & $-3,3$ & $-3,8$ & 62,5 & 67,5 & 70,4 & 72,0 & 73,3 & 7,9 \\
\hline Belgia & $-1,3$ & $-6,0$ & $-4,8$ & $-4,6$ & $-4,7$ & $-3,5$ & 89,6 & 96,2 & 98,6 & 100,5 & 102,1 & 9,0 \\
\hline Cypr & 0,9 & $-6,0$ & $-5,9$ & $-5,7$ & $-5,7$ & $-6,8$ & 48,3 & 58,0 & 62,2 & 65,2 & 68,4 & 13,9 \\
\hline Estonia & $-2,8$ & $-1,7$ & $-1,0$ & $-1,9$ & $-2,7$ & 1,8 & 4,6 & 7,2 & 8,0 & 9,5 & 11,7 & 3,4 \\
\hline Finlandia & 4,2 & $-2,5$ & $-3,1$ & $-1,6$ & $-1,2$ & $-7,3$ & 34,1 & 43,8 & 49,0 & 51,1 & 53,0 & 14,9 \\
\hline Francja & $-3,3$ & $-7,5$ & $-7,7$ & $-6,3$ & $-5,8$ & $-4,4$ & 67,5 & 78,1 & 83,0 & 86,8 & 89,8 & 15,5 \\
\hline Grecja & $-9,4$ & $-15,4$ & $-9,6$ & $-7,4$ & $-7,6$ & $-0,2$ & 110,3 & 126,8 & 140,2 & 150,2 & 156,0 & 29,9 \\
\hline Hiszpania & $-4,2$ & $-11,1$ & $-9,3$ & $-6,4$ & $-5,5$ & $-5,1$ & 39,8 & 53,2 & 64,4 & 69,7 & 73,0 & 24,6 \\
\hline Holandia & 0,6 & $-5,4$ & $-5,8$ & $-3,9$ & $-2,8$ & $-6,4$ & 58,2 & 60,8 & 64,8 & 66,6 & 67,3 & 6,6 \\
\hline Irlandia & $-7,3$ & $-14,4$ & $-32,3$ & $-10,3$ & $-9,1$ & $-25,0$ & 44,3 & 65,5 & 97,4 & 107,0 & 114,3 & 53,1 \\
\hline Luksemburg & 3,0 & $-0,7$ & $-1,8$ & $-1,3$ & $-1,2$ & $-4,8$ & 13,6 & 14,5 & 18,2 & 19,6 & 20,9 & 4,6 \\
\hline Malta & $-4,8$ & $-3,8$ & $-4,2$ & $-3,0$ & $-3,3$ & 0,6 & 63,1 & 68,6 & 70,4 & 70,8 & 70,9 & 7,3 \\
\hline Niemcy & 0,1 & $-3,0$ & $-3,7$ & $-2,7$ & $-1,8$ & $-3,8$ & 66,3 & 73,4 & 75,7 & 75,9 & 75,2 & 9,4 \\
\hline Portugalia & $-2,9$ & $-9,3$ & $-7,3$ & $-4,9$ & $-5,1$ & $-4,4$ & 65,3 & 76,1 & 82,8 & 88,8 & 92,4 & 17,5 \\
\hline Słowacja & $-2,1$ & $-7,9$ & $-8,2$ & $-5,3$ & $-5,0$ & $-6,1$ & 27,8 & 35,4 & 42,1 & 45,1 & 47,4 & 14,3 \\
\hline Słowenia & $-1,8$ & $-5,8$ & $-5,8$ & $-5,3$ & $-4,7$ & $-4,0$ & 22,5 & 35,4 & 40,7 & 44,8 & 47,6 & 18,2 \\
\hline Włochy & $-2,7$ & $-5,3$ & $-5,0$ & $-4,3$ & $-3,5$ & $-2,3$ & 106,3 & 116,0 & 118,9 & 120,2 & 119,9 & 12,6 \\
\hline Strefa euro & $-2,0$ & $-6,3$ & $-6,3$ & $-4,6$ & $-3,9$ & $-4,3$ & 69,7 & 79,1 & 84,1 & 86,5 & 87,8 & 14,4 \\
\hline Unia Europejska & $-2,3$ & $-6,8$ & $-6,8$ & $-5,1$ & $-4,2$ & $-4,5$ & 61,8 & 74,0 & 79,1 & 81,8 & 83,3 & 17,3 \\
\hline
\end{tabular}

Źródło: opracowanie własne na podstawie: General government data. Autumn 2010, Komisja Europejska, 2010, ec.europa.eu (data dostępu: 21.01.2011 r.), s. 154, 166.

W zakresie długu publicznego tendencje w poszczególnych państwach strefy euro są już istotnie zbliżone (tab. 2). W latach 2008-2010 wszystkie te kraje charakteryzował trend wzrostowy na tym polu, będący pochodną ujemnych sald budżetowych. Rekordowy przyrost zadłużenia należy odnotować w Irlan- 
dii (o ponad połowę rocznego PKB), ale także w Grecji (i jest to jednocześnie kraj o najwyższym względnym poziomie długu w strefie euro) i Hiszpanii (o ok. 25-30\% PKB). Warto wspomnieć, że powrót tendencji wzrostowej dotyczy m.in. Belgii, Grecji i Włoch, tj. krajów, które pod koniec lat dziewięćdziesiątych warunkowo przyjęto do strefy euro pomimo ogromnych rozmiarów zadłużenia (ponad $100 \%$ PKB), wymuszając na nich wdrażanie wieloletnich programów obniżania jego poziomu. Efekty tych działan - skądinąd raczej mizerne, choć w praktyce faktycznie występujące - zostały zatem obecnie zaprzepaszczone. Podkreślić należy, że według stanu na rok 2010 dług publiczny nie większy niż 60\% PKB, czyli zgodny z poziomem wyznaczonym przez kryteria konwergencji, charakteryzuje jedynie pięć państw strefy euro - Estonię, Finlandię, Luksemburg, Słowację i Słowenię. Prognozy Komisji Europejskiej ${ }^{17}$ wskazują na utrzymanie w kolejnych latach tendencji wzrostowej w zakresie długu publicznego, zatem na szybkie zwiększenie tej liczby nie należy raczej liczyć.

Warto także przypomnieć, że pomimo funkcjonowania w prawodawstwie unijnym omówionej wcześniej procedury nadmiernego deficytu do tej pory była ona bardzo mało skuteczna w dyscyplinowaniu krajów członkowskich do utrzymywania równowagi finansów publicznych - głównie, jak się wydaje, dlatego, że z przyczyn politycznych nie nakładano żadnych sankcji finansowych. Chociaż na początku pierwszej dekady XXI w. objętej tą procedurą Portugalii udało się ograniczyć deficyt poniżej 3\% PKB z wyjściowych ponad 4\%, to jednak już Niemcy czy Francja (a także Grecja i Włochy) wówczas przez wiele lat właściwie bezkarnie lekceważyły wymogi traktatowe, co zresztą wywoływało wiele kontrowersji ${ }^{18}$.

Długookresowe utrzymywanie wysoce ujemnego salda finansów publicznych przez Grecję było jedną z podstawowych przyczyn wystąpienia tzw. kryzysu greckiego pod koniec roku 2009. Władze tego kraju dodatkowo przez wiele lat fałszowały dane statystyczne w tym zakresie i ujawnienie tego procederu doprowadziło do załamania ich wiarygodności, ratingu papierów wartościowych oraz zaufania inwestorów i skoku rentowności obligacji emitowanych przez Grecję ${ }^{19}$.

Negatywne zjawiska w sferze finansów publicznych szybko rozprzestrzeniły się na kilka innych krajów strefy euro - szczególnie Irlandię, Portugalię i Hiszpanię. Wyrazem tego był $\mathrm{w}$ tych państwach $\mathrm{z}$ jednej strony sięgający $10-15 \%$ PKB deficyt sektora w roku 2009, z drugiej - wzrost w ślad za przypadkiem Grecji rentowności obligacji. W grudniu 2010 r. dysparytet stóp procentowych w tym zakresie względem papierów niemieckich (rentowność ok. 2,5-3\%) sięgał w przypadku Grecji aż ponad 9\%, Irlandii - ok. 5,5\%, Portugalii - prawie 4,5\%

17 General government, s. 166.

18 Por. Finanse Unii Europejskiej, red. B. Bernaś, Wyd. AE, Wrocław 2005, s. 124.

19 Kryzys grecki-geneza i konsekwencje, Ministerstwo Finansów, Warszawa 2010, s. 14-15. 
(wykres). Warto nadmienić, że do roku 2007 różnica pomiędzy najwyższą a najniższą rentownością obligacji emitowanych przez kraje strefy euro nie przekraczała zasadniczo 0,5\% (!). Zwiększenie stopnia dywersyfikacji stopy procentowej w państwach unii walutowej oznaczać może, że obecnie większe znaczenie dla jej kształtowania będzie miała premia za ryzyko, a mniejsze - rodzaj waluty, w której papiery są nominowane, czy sam fakt posługiwania się wspólnym pieniądzem ${ }^{20}$. W konsekwencji kraje o niższej wiarygodności polityki gospodarczej czy bardziej rozchwianym systemie finansów publicznych w mniejszym stopniu mogą i, jak się wydaje, będą mogły liczyć na istotne obniżenie rentowności własnych papierów skarbowych na skutek przynależności (czy akcesji) do strefy euro.

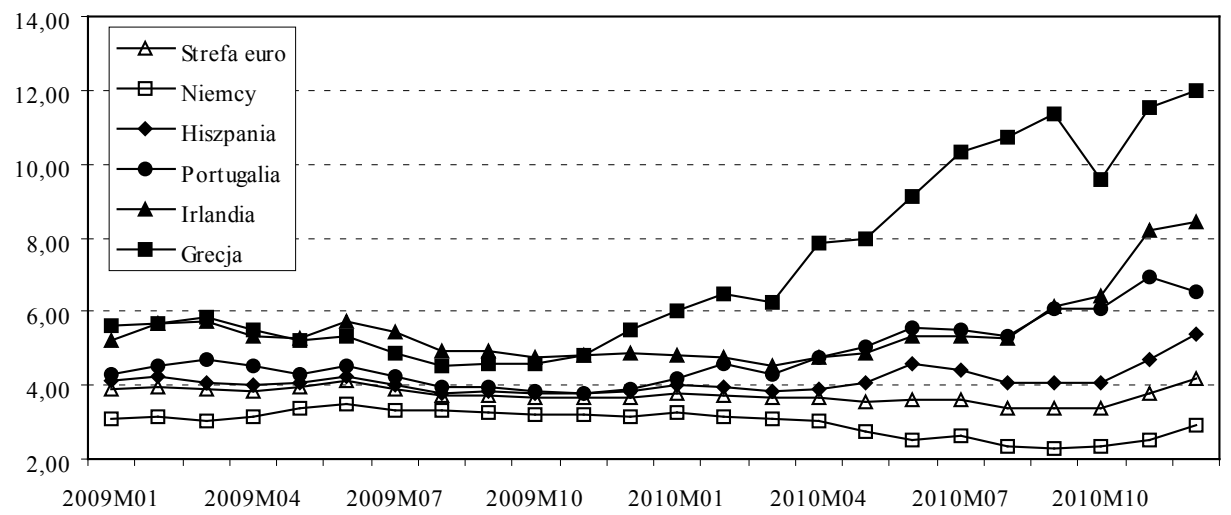

Wykres. Rentowność dziesięcioletnich obligacji skarbowych w wybranych krajach strefy euro $(\mathrm{w} \%)$

Źródło: opracowanie własne na podstawie danych Eurostatu, epp.eurostat.cec.eu.int (data dostępu: 21.02.2011 r.).

W celu złagodzenia zjawisk kryzysowych w Grecji, a później w innych krajach dotkniętych zwiększonym ryzykiem niewypłacalności pozostałe państwa europejskie rozpoczęły działania ukierunkowane na wsparcie finansowe, choć pojawiały się też inne, bardziej kontrowersyjne propozycje, takie jak np. wykluczenie zadłużonych krajów ze strefy euro czy dopuszczenie do ich bankructwa ${ }^{21}$. Przepisy traktatowe wprowadzają jednak zasadę - której dotychczas konsekwentnie przestrzegano - samodzielnej odpowiedzialności państw Unii Europejskiej za własne

20 Por. także Kryzys grecki, s. 16; M. Ehrmann, M. Fratzscher, R.S. Gürkaynak, E.T. Swansons, Convergence and Anchoring of Yield Curves in the Euro Area, „ECB Working Paper Series” 2007, No. 817, s. 25-26; S. Barrios, P. Iversen, M. Lewandowska, R. Setzers, Determinants of Intra-Euro Area Government Bond Spreads During the Financial Crisis, „European Economy - Economic Papers" 2009, No. 388, s. 24.

21 Kryzys grecki, s. 18-24. 
zobowiązania budżetowe, choć w innym miejscu stanowią, że „w przypadku gdy państwo członkowskie ma trudności [...] z racji [...] nadzwyczajnych okoliczności pozostających poza jego kontrolą, Rada [...] może przyznać danemu państwu [...] wspólnotową pomoc finansową"22. To stwierdzenie pozwoliło uznać, że greckie problemy spowodowane były „nadzwyczajnymi okolicznościami” i uchwalić stabilizacyjny fundusz pomocowy o wartości 110 mld EUR, a także podjąć inne działania ukierunkowane na przywrócenie wiarygodności gospodarce Grecji ${ }^{23}$. W 2010 r. powołano także tzw. Europejski Mechanizm Stabilizacyjny o wartości 750 mld EUR - najpierw w postaci tymczasowej, a od roku 2013 ma on stanowić stały fundusz antykryzysowy. Pod koniec roku 2010 uchwalono jeszcze przyznanie pomocy finansowej Irlandii ( 85 mld EUR).

Takie podejście sprawia, że kraje - zarówno obecni, jak i przyszli członkowie strefy euro - o tradycyjnie słabszej dyscyplinie finansów publicznych moga liczyć na wsparcie innych państw Unii w sytuacji kryzysowej i odczuwać pokusę mniejszej dbałości o równowagę fiskalną niż w sytuacji, gdyby były zdane same na siebie. Aby przeciwdziałać takiemu zjawisku, a przede wszystkim aby zwiększyć poziom stabilności systemu finansowego Unii Europejskiej, Komisja proponuje nowelizację obowiązujących przepisów, szczególnie w zakresie norm prewencyjnych zawartych w Pakcie Stabilności i Wzrostu, wprowadzenia ścisłego monitorowania poziomu długu publicznego (podobnie jak to jest obecnie, jeśli chodzi o deficyt budżetowy), zaostrzenia kar za nieprzestrzeganie dyscypliny fiskalnej i modyfikacji procedury ich nakładania. Rozważana jest także możliwość emisji wspólnych obligacji państw należących do unii walutowej, regularnego obserwowania różnych wskaźników makroekonomicznych krajów, ścisłego koordynowania polityk ekonomicznych (a nawet ujednolicenia władz gospodarczych strefy euro) czy poszerzenia kompetencji Eurostatu o kontrolę jakości danych dostarczanych przez państwa $\mathrm{UE}^{24}$.

\section{PERSPEKTYWY ROZSZERZENIA STREFY EURO}

W większości krajów Unii Europejskiej spoza strefy euro nierównowagi fiskalne są, jak się wydaje, nawet głębsze niż w przypadku państw posługujących się wspólną walutą. Wynika to w dużej mierze $\mathrm{z}$ faktu, że jeszcze przed pojawieniem się globalnego kryzysu w wielu z tych gospodarek występowały wysokie deficy-

22 Art. 103 ust. $1 \mathrm{i}$ art. 100 ust. 2 Traktatu.

23 Por. E. Gostomski, Remedial measures for public finance in the European Union countries, [w:] The Mechanism of Functioning of EMU. Euro Zone Enlargement - the New Members' Perspective, red. J. Bilski, E. Feder-Sempach, Wyd. Uniw. Eódzkiego, Łódź 2010, s. 83; Kryzys grecki, s. 22.

${ }_{24}$ Por. Kryzys grecki, s. 30-34. 
ty budżetowe, które zresztą właśnie nie pozwalały na przystąpienie do obszaru wspólnego pieniądza. O ile bowiem w roku 2008 spośród siedemnastu obecnych krajów członkowskich strefy euro jedynie pięć (niecała jedna trzecia) charakteryzowało saldo sektora general government na poziomie niższym niż minus 3\% $\mathrm{PKB}$, o tyle wśród reszty państw UE było to już sześć na dziesięć. Kryzys spowodował dalsze pogorszenie sytuacji w tym zakresie - wszystkie kraje spoza strefy wspólnego pieniądza do roku 2010 jeszcze bardziej pogłębiły deficyt budżetowy - najmniej Węgry (o 0,1\% PKB), najbardziej Dania (o 8,3\% PKB). Wskaźnik ten, pomimo znacznego spadku, udało się utrzymać w ryzach (tzn. na dopuszczalnym przez kryteria konwergencji poziomie) jedynie Szwecji. Ogólnie jednak, jak wspomniano, w porównaniu do krajów strefy euro pozostałe państwa UE osiągają pod tym względem słabsze wyniki. Całkowity deficyt sektora general government gospodarek o wspólnej walucie w 2010 wyniósł 6,3\% PKB, przy tym wskaźniku dla 27 krajów UE już na poziomie 6,8\% PKB (tabela 3).

$\mathrm{Z}$ drugiej strony jednak, wśród krajów spoza strefy euro jest wiele o tradycyjnie niewielkim poziomie długu publicznego i nawet pomimo jego istotnego wzrostu na skutek zjawisk kryzysowych, prognozuje się, że w ciągu najbliższych lat bezpieczny poziom $60 \% \mathrm{PKB}$ nie zostanie w wielu przypadkach przekroczony (tab. 3). Do tej grupy należą np. Bułgaria (zadłużenie na poziomie ok. 18\% PKB w roku 2010), Rumunia (ok. 30\%) czy Litwa (ok. 37\%). Warto jednak dla porządku nadmienić o sytuacji Wielkiej Brytanii i Węgier, gdzie wskaźnik ten sięga prawie $80 \%$ PKB i nadal niepokojąco szybko rośnie.

Pomimo faktu, że obecnie (według wstępnych danych za rok 2010) fiskalnych kryteriów konwergencji poza Szwecją nie spełnia żaden z krajów UE nie posługujący się euro, prognozy dają nadzieję na dość szybkie unormowanie sytuacji w kolejnych państwach. Komisja Europejska ocenia, że do roku 2012 równowaga budżetowa powróci jeszcze w Bułgarii, a na granicy dopuszczalnego poziomu znajdzie się Dania i Rumunia (tab. 3) ${ }^{25}$. Z kolei dług publiczny, mimo zasadniczego prognozowanego pogorszenia sytuacji pod tym względem, nie rośnie na tyle szybko, by zagrozić wypełnieniu przez te państwa kryteriów konwergencji. Najgorzej w tym zakresie wypadają natomiast wcześniej wspomniane Węgry i Wielka Brytania, ale także Polska - w 2012 r. dług publiczny osiągnie poziom 59,6\% PKB, a więc na granicy dozwolonego pułapu, co niezbyt dobrze rokuje, zwłaszcza wobec prognozowanego deficytu równego wówczas aż $6 \% \mathrm{PKB} . \mathrm{Na}$ marginesie warto zaznaczyć, że na spełnienie warunków konwergencji fiskalnej w kolejnych krajach w najbliższym czasie dają także nadzieję pojawiające się propozycje organów wspólnotowych odliczenia przy kalkulacji deficytu całości lub

25 General government, s. 155. 
części kosztów reformy emerytalnej (w przypadku Polski to ok. 1-1,6\% PKB rocznie $\left.{ }^{26}\right)$.

Tabela 3. Wypełnianie fiskalnych kryteriów konwergencji przez kraje UE spoza strefy euro w latach 2008-2012

\begin{tabular}{|c|c|c|c|c|c|c|c|c|c|c|c|c|}
\hline WSKAŻNIK & \multicolumn{6}{|c|}{ SaLdO BUdŻETOWE W RELACI DO PKB (w \%) } & \multicolumn{6}{|c|}{ Dtug PUBLICZNY W RELACI DO PKB (w \%) } \\
\hline Rok & 2008 & 2009 & $2010^{*}$ & $2011^{*}$ & $2012^{*}$ & $2008-2010^{\wedge}$ & 2008 & 2009 & $2010^{*}$ & $2011^{*}$ & $2012^{*}$ & $2008-2010^{\wedge}$ \\
\hline Bułgaria & 1,7 & $-4,7$ & $-3,8$ & $-2,9$ & $-1,8$ & $-5,5$ & 13,7 & 14,7 & 18,2 & 20,2 & 20,8 & 4,5 \\
\hline Czechy & $-2,7$ & $-5,8$ & $-5,2$ & $-4,6$ & $-4,2$ & $-2,5$ & 30,0 & 35,3 & 40,0 & 43,1 & 45,2 & 10,0 \\
\hline Dania & 3,2 & $-2,7$ & $-5,1$ & $-4,3$ & $-3,5$ & $-8,3$ & 34,1 & 41,5 & 44,9 & 47,5 & 49,2 & 10,8 \\
\hline Litwa & $-3,3$ & $-9,2$ & $-8,4$ & $-7,0$ & $-6,9$ & $-5,1$ & 15,6 & 29,5 & 37,4 & 42,8 & 48,3 & 21,8 \\
\hline Łotwa & $-4,2$ & $-10,2$ & $-7,7$ & $-7,9$ & $-7,3$ & $-3,5$ & 19,7 & 36,7 & 45,7 & 51,9 & 56,6 & 26,0 \\
\hline Polska & $-3,7$ & $-7,2$ & $-7,9$ & $-6,6$ & $-6,0$ & $-4,2$ & 47,1 & 50,9 & 55,5 & 57,2 & 59,6 & 8,4 \\
\hline Rumunia & $-5,7$ & $-8,6$ & $-7,3$ & $-4,9$ & $-3,5$ & $-1,6$ & 13,4 & 23,9 & 30,4 & 33,4 & 34,1 & 17,0 \\
\hline Szwecja & 2,2 & $-0,9$ & $-0,9$ & $-0,1$ & 1,0 & $-3,1$ & 38,2 & 41,9 & 39,9 & 38,9 & 37,5 & 1,7 \\
\hline Węgry & $-3,7$ & $-4,4$ & $-3,8$ & $-4,7$ & $-6,2$ & $-0,1$ & 72,3 & 78,4 & 78,5 & 80,1 & 81,6 & 6,2 \\
\hline Wlk. Brytania & $-5,0$ & $-11,4$ & $-10,5$ & $-8,6$ & $-6,4$ & $-5,5$ & 52,1 & 68,2 & 77,8 & 83,5 & 86,6 & 25,7 \\
\hline Strefa euro & $-2,0$ & $-6,3$ & $-6,3$ & $-4,6$ & $-3,9$ & $-4,3$ & 69,7 & 79,1 & 84,1 & 86,5 & 87,8 & 14,4 \\
\hline Unia Europejska & $-2,3$ & $-6,8$ & $-6,8$ & $-5,1$ & $-4,2$ & $-4,5$ & 61,8 & 74,0 & 79,1 & 81,8 & 83,3 & 17,3 \\
\hline
\end{tabular}

Źródło: opracowanie własne na podstawie: General government data. Autumn 2010. Komisja Europejska, 2010, ec.europa.eu (data dostępu; 21.01.2011 r.), s. 155, 167.

Należy również pamiętać, że zgodnie z treścią zapisów traktatowych uznanie, że globalny kryzys gospodarczy jest zjawiskiem o charakterze „wyjątkowym” i „tymczasowym” może stanowić przesłankę do stwierdzenia, iż przekroczenie

26 Por. np. Program konwergencji. Aktualizacja 2009, Rada Ministrów RP, Warszawa 2010; Komunikat dot. porozumienia pomiędzy Komisją Europejskq i Polskq w sprawie uwzględniania kosztów emerytalnych, www.mf.gov.pl, (data dostępu: 21.01.2011 r.); A. Słojewska, K. Ostrowska, Rzqd wygrat w Brukseli batalię o koszty OFE, „Rzeczpospolita” 11.12.2010 r., s. B1; Zgoda Barroso. Rzqd wliczy koszty reformy emerytalnej do deficytu, www.money.pl (data dostępu 21.01.2011 r.); Koszty reformy emerytalnej nie będq wliczane do dtugu i deficytu publicznego, www.pb.pl (data dostępu 21.01.2011 r.); $K E$ nie będzie uwzględniać kosztów reformy emerytalnej przy liczeniu dtugu, www.bankier.pl (data dostępu 21.01.2011 r.). 
z jego przyczyny dopuszczalnego pułapu przez deficyt budżetowy nie stanowi braku poszanowania dyscypliny finansów publicznych ${ }^{27}$. W konsekwencji kryterium konwergencji mimo zbyt wysokiej wartości wskaźnika może zostać uznane za spełnione. Podobnie wygląda sytuacja, jeśli chodzi o dług publiczny, przy czym tu już - zgodnie z postanowieniami prawa europejskiego - wymagana jest tendencja spadkowa tego miernika ${ }^{28}$. Warto więc sobie uświadomić, że można dostarczyć zarówno argumentów za uznaniem, że największy ogólnoświatowy kryzys gospodarczy ostatnich kilkudziesięciu lat faktycznie jest zjawiskiem wyjątkowym i przypuszczalnie tymczasowym, jak i udowadniać coś zupełnie przeciwnego - kryzys miał przecież swoje narastające przez wiele lat, więc zupełnie „niewyjątkowe” przyczyny, a to, czy jest tymczasowy, można stwierdzić dopiero $\mathrm{w}$ istocie $\mathrm{z}$ perspektywy długookresowej. W takich warunkach zatem ocena wypełniania kryteriów fiskalnych przez kolejne kraje stojące u bram strefy euro będzie miała charakter w dużej mierze jakościowy, subiektywny czy - można nawet rzec - dowolny, w związku z czym, jak się wydaje, będzie podporządkowana bieżącym względom politycznym (chęci bądź niechęci do rozszerzenia obszaru wspólnego pieniądza).

Kryzys grecki sprawił, że nastawienie państw unii walutowej względem dalszego jej rozszerzania, zwłaszcza o kraje o tradycyjnej czy strukturalnej nierównowadze finansów publicznych, stało się z pewnością mniej entuzjastyczne. Wyrazem tego są choćby wspomniane radykalne propozycje ewentualnego wykluczenia zadłużonych państw ze strefy euro. $Z$ drugiej strony należy pamiętać, że światowa recesja uwidoczniła także istotne słabości integracji walutowej. Likwidacja kursu walutowego i autonomicznej polityki monetarnej jako narzędzi amortyzujących egzogeniczne wstrząsy gospodarcze sprawiła, że zjawiska kryzysowe (w tym i nierównowaga fiskalna) szybko rozprzestrzeniły się po obszarze wspólnego pieniądza. Z kolei kraje o odrębnych walutach i nieusztywnionych kursach (tu sztandarowym przykładem jest Polska, ale również np. Czechy) sama recesja, a także np. wzrost rentowności papierów skarbowych, dotknęła zasadniczo w mniejszym stopniu. Te doświadczenia - jak się wydaje - mogą wpływać na decyzje władz, a także poglądy społeczeństw państw Unii Europejskiej spoza strefy wspólnego pieniądza, w zakresie terminu czy w ogóle celowości wymiany walut narodowych na euro. Negatywnych odczuć na tym polu może nie zrekompensować nawet stworzenie procedur antykryzysowych, potencjalna możliwość istotnego wspar-

27 Zgodnie z art. 2 ust. 1 Rozporzqdzenia Rady (WE) nr 1467/97 z dnia 7 lipca 1997 r. w sprawie przyspieszenia $i$ wyjaśnienia procedury nadmiernego deficytu (OJ L 209, 02.08.1997, s. 6, z późn. zm.), ,przekroczenie przez deficyt publiczny wartości bazowej uznaje się za wyjątkowe i tymczasowe $[. .$.$] , gdy wynika ono [...] ze znacznego pogorszenia koniunktury gospodarczej".$

28 Art. 104 ust. 2 Traktatu. 
cia w sytuacji trudności ze zrównoważeniem budżetu czy planowane zacieśnienie współpracy wewnątrz unii walutowej w zakresie polityki gospodarczej.

\section{ZAKOŃCZENIE}

Równowaga finansów publicznych, której wyrazem w świetle litery i ducha ustawodawstwa europejskiego jest odpowiednio niskie saldo sektora general government, a także ograniczony poziom długu publicznego, od dłuższego czasu z jednej strony stanowi - przynajmniej oficjalnie - jeden z ważniejszych celów polityk gospodarczych poszczególnych krajów członkowskich Unii Europejskiej, a z drugiej - wielu państwom sprawia istotne trudności w utrzymywaniu. Konstrukcja prawna w postaci procedury nadmiernego deficytu w dotychczasowej postaci uległa - można rzec - kompromitacji, gdy na skutek jej nieskuteczności, a także fałszerstw statystycznych Grecji doszło do kryzysu finansów publicznych w kilku krajach członkowskich Wspólnoty. Udzielenie wsparcia przez resztę państw, a także odpowiednie korekty przepisów - głównie prewencyjnych - stały się niezbędne dla zapobieżenia dalszym negatywnym zjawiskom, które w przyszłości mogłyby doprowadzić do jeszcze głębszego załamania w europejskiej gospodarce.

Obserwacja tych tendencji jest istotna dla przyjęcia odpowiednich planów względem integracji walutowej przez państwa Unii Europejskiej, które jeszcze nie posługują się wspólnym pieniądzem, w tym przez Polskę. Mogą one bowiem w praktyce wybrać termin akcesji do strefy euro - bądź, tak jak Wielka Brytania i Dania mając to zagwarantowane odpowiednimi postanowieniami traktatowymi, bądź po prostu opóźniając moment wprowadzenia waluty do mechanizmu ERM2 czy wypełnienia innych kryteriów konwergencji. Zasadniczo bowiem, jak wskazywano, przyczyny, przebieg i skutki światowej depresji i załamania greckiego obnażyły istotną wagę niekorzyści, które niesie ze sobą funkcjonowanie unii walutowej.

Podsumowując można stwierdzić, że w dobie globalnego kryzysu znacznie trudniej niż w okresie wzrostu gospodarczego jest nie tylko przywrócić czy zachować równowagę finansów publicznych, ale także kontynuować proces integracji walutowej w Europie. Wynika to zarówno z problemów ze spełnieniem kryteriów konwergencji decydujących o przystąpieniu do strefy euro, jak i z mniejszego entuzjazmu względem tego przedsięwzięcia - w krajach posługujących się wspólnym pieniądzem, ale także w tych dopiero do tego aspirujących. 


\section{BIBLIOGRAFIA}

Barrios S., Iversen P., Lewandowska M., Setzers R., Determinants of Intra-Euro Area Government Bond Spreads During the Financial Crisis, „European Economy - Economic Papers” 2009, No. 388.

Barro R.J., Makroekonomia, PWE, Warszawa 1997.

Begg D., Fischer S., Dornbusch R., Ekonomia, t. 2, PWE, Warszawa 1998.

Burda M., Wyplosz Ch., Makroekonomia. Podręcznik europejski, PWE, Warszawa 1995.

Convergence Report May 2007, Europejski Bank Centralny, Frankfurt 2007.

Convergence Report, European Monetary Institute, Frankfurt 1998.

Ehrmann M., Fratzscher M., Gürkaynak R. S., Swansons E.T., Convergence and Anchoring of Yield Curves in the Euro Area, „ECB Working Paper Series” 2007, No. 817.

Finanse Unii Europejskiej, red. B. Bernaś, Wyd. AE, Wrocław 2005.

General government data. Autumn 2010, Komisja Europejska, 2010, ec.europa.eu (data dostępu: 21.01.2011 r.).

Gostomski E., Remedial measures for public finance in the European Union countries, [w:] The Mechanism of Functioning of EMU. Euro Zone Enlargement - the New Members' Perspective, red. J. Bilski, E. Feder-Sempach, Wyd. Uniw. Eódzkiego, Eódź 2010.

Hall R.E., Taylor J.B., Makroekonomia. Teoria, funkcjonowanie i polityka, Wyd. Nauk. PWN, Warszawa 1997.

Kamerschen D.R., McKenzie R.B., Nardinelli C., Ekonomia, Fundacja Gospodarcza NSZZ „Solidarność, Gdańsk 1992.

KE nie będzie uwzględniać kosztów reformy emerytalnej przy liczeniu dtugu, www.bankier.pl (data dostępu: 21.01.2011 r.).

Komunikat dot. porozumienia pomiędzy Komisjq Europejskq i Polskq w sprawie uwzględniania kosztów emerytalnych, www.mf.gov.pl (data dostępu: 21.01.2011 r.).

Koszty reformy emerytalnej nie będq wliczane do dtugu i deficytu publicznego, www.pb.pl (data dostępu: 21.01.2011 r.).

Kryzys grecki-geneza i konsekwencje, Ministerstwo Finansów, Warszawa 2010.

Makroekonomia, red. M. Noga, Wyd. AE, Wrocław 1995.

Müller A., Makroekonomia, PWSH, Warszawa 1996.

Nosek A., Pietrzak A., Efekt domina czyli międzynarodowa transmisja kryzysów - na przyktadzie wspótczesnego kryzysu finansowego, [w:] Wybrane problemy gospodarki swiatowej pierwszej dekady nowego wieku, red. W. Michalczyk, Katedra MSG UE, Wrocław 2009.

Oręziak L., Euro. Nowy pieniqudz, Wyd. Nauk. PWN, Warszawa 2003.

Polityka gospodarcza, red. B. Winiarski, PWN, Warszawa 2006.

Polska wobec światowego kryzysu gospodarczego, NBP, Warszawa 2009, www.nbp.pl (data dostępu: 04.01.2010 r.).

Program konwergencji. Aktualizacja 2009, Rada Ministrów RP, Warszawa 2010.

Protokót w sprawie kryteriów okreslonych w artykule 121 Traktatu ustanawiającego Wspólnote Europejskq dołączony do Traktatu ustanawiającego Wspólnotę Europejskq (OJ C 321, 29.12.2006, s. 37). 
Protokót w sprawie procedury dotyczącej nadmiernego deficytu dołączony do Traktatu ustanawiajacego Wspólnotę Europejskq (OJ C 321, 29.12.2006, s. 37).

Rozporzadzenie Rady (WE) nr 1467/97 z dnia 7 lipca 1997 r. w sprawie przyspieszenia i wyjaśnienia procedury nadmiernego deficytu (OJ L 209, 02.08.1997, s. 6, z późn. zm).

Rozporzadzenie Rady (WE) nr 479/2009 z dnia 25 maja 2009 r. o stosowaniu Protokotu w sprawie procedury dotyczacej nadmiernego deficytu zataczonego do Traktatu ustanawiajacego Wspólnotę Europejskq (OJ L 145, 10.06.2009, s. 1, z późn. zm.).

Samuelson P.A., Nordhaus W. D., Ekonomia, t. 1, PWN, Warszawa 1995.

Słojewska A., Ostrowska K., Rzqdd wygrat w Brukseli batalię o koszty OFE, „Rzeczpospolita” 11.12.2010, s. B1.

Sobczyński D., Euro. Historia, praktyka, instytucje, KiK, Warszawa 2002.

Traktat ustanawiający Wspólnotę Europejskq (OJ C 321, 29.12.2006, s. 37).

Zgoda Barroso. Rzqd wliczy koszty reformy emerytalnej do deficytu, www.money.pl (data dostępu: 21.01.2011 r.).

Zorska A., Korporacje transnarodowe. Przemiany, oddziatywania, wyzwania, PWE, Warszawa 2007.

\section{THE PUBLIC FINANCE EQUILIBRIUM AND THE PROCESS OF EUROPEAN MONETARY INTEGRATION AT A TIME OF GLOBAL CRISIS}

SUMMARY

In the paper, the author presents the effects of an analysis of the impact of the phenomena connected with the global economic crisis on the public finance equilibrium in the European Union member states. The subject matter is also the importance of this equilibrium for the process of the euro area enlargement. The consequences of the global depression for the fulfilment of the fiscal convergence criteria are presented and some forecasts for ensuing years are made. Significant disadvantages of monetary integration affecting the possibility of negative external economic phenomena amortisation are also indicated. The conclusion is that the global crisis seriously hampered the further growth of the euro area. 
